\title{
A NARRATIVA CINEMATOGRÁFICA: O IMBRICAMENTO DE SOM E IMAGEM NA PRODUÇÃO DE SENTIDO EM $O$ CÉU DE SUELY
}

\author{
Narrative film: interweaving of sound and image in the production of meaning \\ in the movie "o céu de suely" (love for sale: suely in the sky)
}

\author{
La narración fílmica: entrelazamiento de som y image na producion de el \\ significado en "o céu de suely" (el cielo suely)
}

Alisson Gutemberg

Universidade Federal do Rio Grande do Norte alissongutemberg.jornalista@gmail.com

Bertrand Lira

Universidade Federal da Paraíba

liraabertrand@gmail.com

\section{Resumo}

O cinema, como meio de expressão, constitui-se como propagador de uma carga simbólica significativa. E, por isso, configura-se como um dos principais agentes no processo de construção das representações sociais que perpetuam-se dentro dos imaginários coletivos. Para tanto, a narrativa cinematográfica apresenta, em sua estruturação - de acordo com Gaudreault; Jost (2009) -, elementos do domínio do não verbal (a imagem, a música e os ruídos) e do verbal (diálogos e menções escritas). Nos interessa aqui observar como a música se organiza no filme $O$ Céu de Suely (Karim Aïnouz, 2006). E, a partir disso, analisar a maneira como ela atua no contexto da narrativa fílmica, isto é, na produção de sentido dentro do universo diegético.

Palavras-chave: Narrativa cinematográfica. Imagem em movimento. Trilha sonora.

\begin{abstract}
Cinema, as a mean of expression, is constituted as a holder of significant symbolic content. Therefore, it is configured as one of the major agents in the social representations construction process, which perpetuates in collective imaginaries. Thereunto, the cinematographic narrative presents, in its structure - according to Gaudreault; Jost (2009) , nonverbal (image, music and noises) and verbal (dialogues and written references) elements. Here, our interest is to observe how the music is organized in the movie O Céu de Suely (Karim Aïnouz, 2006. English: Love for Sale: Suely in the Sky), and, thereafter, analyze how she act in the filmic narrative - i.e. in production of meaning of diegetic universe.
\end{abstract}


Key words: Cinematographic narrative. Motion Picture. Soundtrack.

\section{Resumen}

El cine como medio de expresión es difusor simbólico significativo. Y por lo tanto, se configura como uno de los principales actores en la construcción de las representaciones sociales que se perpetúan dentro del imaginario colectivo. Para tanto, la narración fílmica presenta dentro de su estructura - de acuerdo con Gaudreault; Jost (2009) - elementos del dominio no verbales (imágenes, cancións y ruidos) y verbales (diálogos escritos y referencias). En aras aquí para observar cómo la canción se organiza en la película $\mathrm{O}$ céu de Suely (Karim Aïnouz, 2006. Español: El Cielo de Suely ). Y de ella, analizar la forma en que actúa en el contexto de la narración fílmica, es decir, en la producción de sentido dentro del universo diegético.

Palabras clave: La narración fílmica. Imagen en movimiento. Banda sonora.

\section{A NARRATIVA CINEMATOGRÁFICA}

No entender de Metz (1977), toda narrativa é constituída por cinco aspectos: começo e fim; sequência com duas temporalidades (a da coisa narrada e a da narração); discurso; "desrealização" da coisa narrada - adquirida por meio da consciência de que se trata de uma narrativa -; e, por fim, uma sequência de acontecimentos. A narrativa cinematográfica, por contar com elementos visuais, sonoros e textuais, apresenta características próprias quando comparada com outros meios, como por exemplo, a literatura. Quanto a isso, Gaudreault e Jost (2009, p. 42) destacam que - "contrariamente à língua, que é dedicada a uma sucessão que lhe impõe a linearidade da frase, o cinema pode mostrar várias ações simultaneamente".

Porém é importante ressaltar que nos primeiros anos, o cinema não tinha como prioridade estabelecer uma narrativa. Ele "fora concebido como um meio de registro que não tinha a vocação de contar histórias por procedimentos específicos” (VERNET, 1995, p. 89), seu objetivo era apresentar-se, por exemplo, como um divertimento efêmero de feira, isso graças principalmente aos locais de exibição, os chamados vaudevilles: os filmes dividiam espaço com espetáculos musicais, bebidas. Não primavam pela concentração que uma narrativa necessita.

No entanto, de acordo com Vernet (1995), três aspectos foram fundamentais para o encontro entre o cinema e a narrativa: a imagem figurativa em movimento, a imagem em movimento e a busca pela legitimidade. Com relação ao primeiro, o cinema oferece uma imagem figurativa, porém o fato de representar, de mostrar um objeto, é um ato que implica 
que se quer dizer algo em relação ao objeto, no cinema a imagem de uma casa não é apenas a imagem de uma casa, mas sim um discurso, um enunciado, eis aqui uma casa; já a imagem em movimento remete a transformação e se relaciona com a noção de tempo; e, por fim, a busca da legitimidade foi primordial, pois a tentativa de se igualar as "artes nobres" do século XIX - teatro e literatura - fez com que o cinema também buscasse contar histórias.

No entender de Gaudreault e Jost (2009), pensar a narrativa cinematográfica é se questionar acerca de quem narra o filme. Não há narrativa sem que haja uma instância que narre. Quanto a isso, no cinema, se fala da existência de um "grande imagista" (LAFFAY apud GAUDRAULT; JOST, 2009), responsável pela organização dos planos, o diretor. Ele é o encarregado por todos os elementos imagéticos e sonoros que materializam a narrativa projetada na tela, a partir de suas escolhas. É nessas escolhas que reconhecemos as marcas, que na literatura são chamadas de dêiticos, por meio de indicadores que remetem diretamente ao diretor. No campo literário, por exemplo, percebemos isso na escrita, algo próprio de cada autor, já no cinema, como afirmam Bordwell (2009) e Aumont (2011), as marcas estão ligadas a questão do estilo e se configuram dentro da mise-en-scène.

Sendo assim, neste artigo, discutiremos a narrativa cinematográfica como espaço de materialização do imbricamento entre som e imagem, enxergando os aspectos imagéticos e sonoros por intermédio de características semânticas, como coloca Chion (2011). Haja vista que, ainda segundo o autor, imagem e som atuam na construção do sentido engendrado por meio das obras audiovisuais, e, além disso, fazem parte do conjunto de escolhas pertencentes ao diretor. No entanto, antes de adentrarmos na análise do filme proposto, discutiremos o cinema como produtor de sentido visual e sonoro, compreendendo ambos como elementos imbricados e que se relacionam para produzir sentido no âmbito da linguagem cinematográfica.

\section{O CINEMA E A REPRESENTAÇÃO VISUAL E SONORA}

Os filmes são constituídos por um grande número de imagens fixas (fotogramas), organizadas em sequência que dão uma impressão de movimento, por meio de uma forma plana, delimitada por um quadro. No entender de Aumont (1995), o quadro tem suas dimensões e proporções impostas por dois dados técnicos que definem o formato do filme: largura da película-suporte e as dimensões da janela da câmera. Apesar da limitação espacial, quando assistimos a um filme é como se víssemos uma porção de espaço em três dimensões,

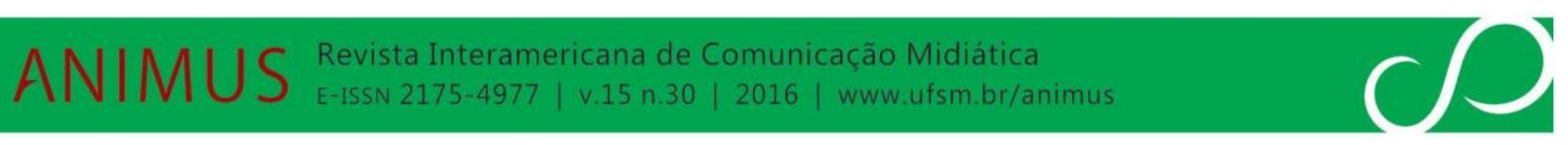


similar ao mundo real. E assim, ainda de acordo com Aumont (1995), tal analogia é responsável por provocar uma "impressão de realidade" que se configura, principalmente, na ilusão de movimento e na ilusão de profundidade de campo.

Com relação à ilusão de movimento, vale destacar que a imagem em movimento é a base fundante do cinema e ela se relaciona com um "realismo" alcançado pelos materiais de expressão do próprio meio que, segundo Gaudreault; Jost (2009), é composto por elementos do domínio do não verbal (a imagem, a música e os ruídos) e do verbal (diálogos e menções escritas), que constituem as cinco matérias de expressão de um filme. Segundo Vernet (1995), entre todas as artes ou modos de representação, o cinema é um dos mais realistas, justamente, entre outras coisas, pela capacidade de reproduzir o movimento. Basta lembrarmo-nos do "ganho de realidade" que tem uma representação cinematográfica quando comparada com uma representação pictórica, por exemplo.

No que se refere ao som, é notório que ele também produz sentido dentro da narrativa cinematográfica, e não apenas a imagem. É importante colocar que a trilha de som, que compõe os filmes, é formada por diálogos, músicas, ruídos, efeitos etc. Aspectos que compõem os domínios do verbal e do não verbal, como coloca Gaudreault e Jost (2009). É preciso lembrar ainda, que o diálogo (aspecto do verbal) é um elemento privilegiado nas análises de conteúdo dos filmes, já que ele estabelece significados mais visíveis em boa parte das narrativas. Mas, neste artigo, nos propomos a analisar principalmente outro aspecto da banda de som, as músicas (aspecto do não verbal).

A relação entre música e imagem em movimento estabelece associações dentro do nosso imaginário, a partir do repertório que construímos ao longo da vida. Basta lembrarmos, por exemplo, de Psicose (Alfred Hitchcock, 1960) e a famosa cena do assassinato no chuveiro, onde a composição de Bernard Hermann estabelece um diálogo eficiente e, ainda hoje, a canção permanece associada a terror, suspense. Outro exemplo que podemos citar é a relação da música Singin'in the rain dentro do filme Cantando na Chuva (Gene Kelly e Stanley Donen, 1952) e a ressignificação que a composição sofre na obra Laranja Mecânica (Stanley Kubrick, 1971).

Podemos mencionar ainda que a música também pode interferir no ritmo da montagem, como acontece, por exemplo, em filmes de Eisenstein. A cena da escadaria de Odessa (O Encouraçado Potemkin, 1925) é um bom exemplo para ilustrar a relação entre ritmo, montagem e banda sonora. Segundo Rosenfeld (2002, p. 143), a canção não é um "elemento subordinado" à trilha de imagem, pois forma com ela "- apesar de seu caráter 
antitético - uma totalidade indivisível, uma Gestalt, um todo integrado": a música proporciona uma dimensão vital que parece faltar à imagem.

Aumont (1995), por sua vez, afirma que entre as características e recursos adotados pelo cinema, ao longo da história, provavelmente a reprodução do som é das que parecem mais naturais. Porém é importante lembrar que a trilha sonora não é um dado tão próprio ao cinema como parece e que, com o passar dos anos, a sua concepção variou muito. Ainda de acordo com Aumont (1995), dois vetores foram e são essenciais nessa variação contínua: os fatores econômico-técnicos e sua história; e os fatores estéticos e ideológicos.

Com relação aos fatores econômico-técnicos e sua história, podemos lembrar que o cinema inicialmente não tinha uma trilha de imagem acompanhada de som gravado. Rosenfeld (2002) especula que o uso inicial da música não tinha fins artísticos, mas sim o propósito de encobrir o barulho incômodo do projetor que dividia espaço com o público. A trilha sonora acompanhava os filmes, porém de forma externa - presente nos locais de exibição -, com um pianista e depois pequenas orquestras. Foram os avanços tecnológicos que posteriormente permitiram o surgimento do cinema sonoro e sua consolidação e, a partir disso, o som passou a ser sincronizado com a imagem no próprio suporte.

Já os fatores estéticos e ideológicos estão imbuídos dentro do escopo que envolve tanto os "ganhos de realidade" que a representação cinematográfica foi adquirindo ao longo do tempo, como também as discussões do cinema como um "duplo" de outras linguagens artísticas já consolidadas. A partir dos anos de 1920, diversos manifestos sobre o cinema sonoro ganharam evidência, como por exemplo, um assinado por Alexandrov, Eisenstein e Pudovkin, "que colocava a não coincidência do som e da imagem como exigência mínima para um cinema não submetido ao teatro" (AUMONT, 1995, p.48).

O que Alexandrov, Eisenstein e Pudovkin diziam guarda uma relação direta com os princípios da montagem soviética. Para eles, a função do som é aumentar a expressividade potencial do conteúdo do filme. Diante disso, tendiam - uns mais, outros menos, eles não pensavam de maneira semelhante - a defender a ideia de que o papel correto do som no cinema era o da não coincidência. Contudo, uma não coincidência radical, capaz de chocar o espectador e convocá-lo a refletir sobre os aspectos expressos nas obras audiovisuais. Em $O$ Céu de Suely não há o uso da música com o intuito de chocar o espectador e provocar uma reflexão ativa, como colocam Alexandrov, Eisenstein e Pudovkin, contudo, no filme de Karim Aïnouz, a banda de som apresenta características importantes em sua relação com a narrativa visual. A cena de abertura é um exemplo. Nela, a canção Tudo que eu tenho, interpretada por 
Diana, dialoga harmonicamente com o momento romântico protagonizado por Hermila e Matheus, mas sua letra aponta um desfecho diferente, levando em consideração as imagens, sobre o que acontece com o casal durante a narrativa.

No que tange à relação de som e imagem, de acordo com Chion (2011), a abordagem que observa a linguagem visual e a sonora separadamente, de forma estrutural, e no entrecorte destas, visando uma compreensão conjunta, torna-se mais assertiva. Chion (2011) demonstra que a percepção singular em paralelo com uma análise conjunta possibilita um entendimento mais amplo da significação da banda sonora (ruídos, diálogos e músicas) de um filme, processo que o autor denomina por "audiovisão". E desta forma, o autor alerta que:

\begin{abstract}
a consequência para o filme é que o som, mais do que a imagem, pode tornar um escondido significado de afetividade em uma manipulação semântica. Por um lado, o som trabalha diretamente, psicologicamente (barulhos de respiração em um filme podem diretamente afetar a nossa respiração). Por outro lado, o som tem uma influência na percepção: através do fenômeno da adição de valores, ele interpreta o significado da imagem, e nos faz ver na imagem o que nós não iremos ver, ou o que veremos diferente. $\mathrm{E}$ então, nós veremos que aquele som não é todo investido e localizado no mesmo caminho da imagem. (CHION apud MARCOLINO, 2012, p. $34)$.
\end{abstract}

Sendo assim, nossa proposta é estabelecer um diálogo entre trilha sonora e trilha de imagem, tendo como elemento norteador as ideias de Chion (2011), por meio de uma observação singular e em conjunto, observando o caráter da trilha de som (precisamente as músicas) como fator de influência nas percepções, emoções e/ou reações do espectador. Nosso intuito é observar de que forma o imbricamento de som e imagem, atentando para o caráter semântico do som, produz sentido dentro da narrativa fílmica. Para tanto, como já mencionamos, utilizaremos o filme $O$ Céu de Suely, nas linhas que seguem, como objeto de investigação e análise.

\title{
3 ANÁLISE DE ALGUMAS CENAS DE O CÉU DE SUELY
}

O filme de Karim Aïnouz apresenta a trajetória de Hermila - uma jovem de 21 anos, natural de Iguatu (interior do Ceará) - que foi tentar a vida em São Paulo junto com o namorado, Matheus. Todavia, por conta do desemprego, a personagem retorna para Iguatu com o filho recém-nascido. Hermila aguarda por um mês o retorno de Matheus, pai da criança, que some sem deixar pistas. Ao perceber que foi abandonada resolve mudar de vida. Liberta-se do amor que sente por Matheus e se envolve com João - um ex-namorado da adolescência - e, posteriormente, decide fazer do corpo uma alternativa para mudar de vida e 
novamente de cidade. Adota o pseudônimo de Suely e resolve rifar uma noite de sexo. É em um contexto de espera, desapego, preconceito e choque com os valores morais, que Karim Aïnouz constrói a narrativa de $O$ Céu de Suely.

Para analisar a obra, adotamos como instrumental metodológico algumas das questões colocadas por Vanoye; Goliot-Lété (1994) e Chion (2011). No que tange as ideias de Vanoye; Goliot-Lété (1994) adotamos os pressupostos referentes à análise fílmica; já de Chion (2011), a abordagem sobre o som no cinema. Para Vanoye; Goliot-Lété (1994), analisar um filme é o mesmo que decompor. É como se analisa, por exemplo, a composição química de uma substância. O processo é dividido em duas etapas. Primeiro é preciso decompor o filme, descrever e, posteriormente, estabelecer e analisar as relações entre os elementos decompostos, interpretar. O objetivo da análise é explicar e esclarecer o funcionamento de uma determinada obra. Para Penafria (2009), quando o cinema é observado apenas no conteúdo não o diferenciamos do teatro ou da literatura. No entender da autora, a análise do conteúdo é importante para conhecer o contexto social, político e cultural, mas sozinha não sana as lacunas expostas por um filme. É preciso descrever e observar os aspectos próprios do meio.

Já a observação do som no cinema, segundo Chion (2011), requer uma abordagem precisa. A trilha sonora (música, efeitos sonoros e voz) também surge como protagonista em qualquer obra audiovisual. Em seu entender, o estudo de cada inserção de som tem importância frente ao material fílmico, e não se trata, simplesmente, de um mero acompanhamento da imagem. De acordo com Chion (2011), por meio da análise das particularidades de cada inserção sonora, colhemos resultados precisos na confecção dos sentidos produzidos para cada filme. E o conceito de "audiovisão" é uma das maiores contribuições que Chion (2011) oferece para o estudo do som no cinema, trata-se da compreensão da imagem e do som como elementos imbricados, pois, para ele, não se pode observar o som de um filme independente de sua imagem e vice-versa.

É por isso que utilizamos os conceitos apresentados acima na observação do filme proposto. Nosso intuito é compreender a forma como música e imagem produzem sentindo dentro de $O$ Céu de Suely. Além disso, buscamos observar como a obra se relaciona no contexto inserido e na história. Vale salientar que, no entender de Vanoye e Goliot-Lété (1994), a análise fílmica nem sempre requer uma observação minuciosa da obra como um todo. $\mathrm{O}$ analista pode escolher uma sequência que seja importante e consiga traduzir as ideias 
presentes no filme. Sendo assim, nossa análise consistirá na descrição da sequência de abertura da obra. O intuito é que a escolha possa satisfazer os nossos almejos.

A cena citada contém nove planos e 1'48". Observamos uma imagem com "tom envelhecida" que transparece a ideia de registro pessoal. Em plano médio aparece Hermila sorridente, caminhando, com ângulos que variam entre lateral e traseiro, em um campo de areia. Em voz off a personagem começa a narrar: "eu fiquei grávida num domingo de manhã. Tinha cobertor azul de lã escura. Matheus me pegou pelo braço e disse que ia me fazer a pessoa mais feliz do mundo, me deu um CD gravado com todas as músicas que eu mais gostava. Ele disse que queria casar comigo, ou então morrer afogado."

Enquanto o texto é narrado em voz off, em plano conjunto e em ângulo traseiro, Matheus e Hermila aparecem correndo. Matheus alcança Hermila, abraça e beija, e ambos caminham abraçados. A câmera gira numa panorâmica e tem início a canção interpretada por Diana: "que bom seria ter / seu amor outra vez / você me fez sonhar / trouxe a fé que eu perdi / e nem eu mesma sei por que / eu só quero amar você / tudo que eu tenho meu bem é você / sem seu carinho eu não sei viver / tudo que eu tenho meu bem é você / volte logo, meu amor." Enquanto a música continua de forma extra-diegética, em plano conjunto os dois permanecem abraçados (Figura 1), em seguida se separaram e sorriem. A cena segue e os personagens se abraçam e se beijam. Separam-se novamente e, mais uma vez, sorriem. Voltam a se abraçar. A câmera faz uma panorâmica, até que a música chega no trecho: "volte logo, meu amor..." e a sequência termina.

Figura 1: Hermila e Matheus abraçados.

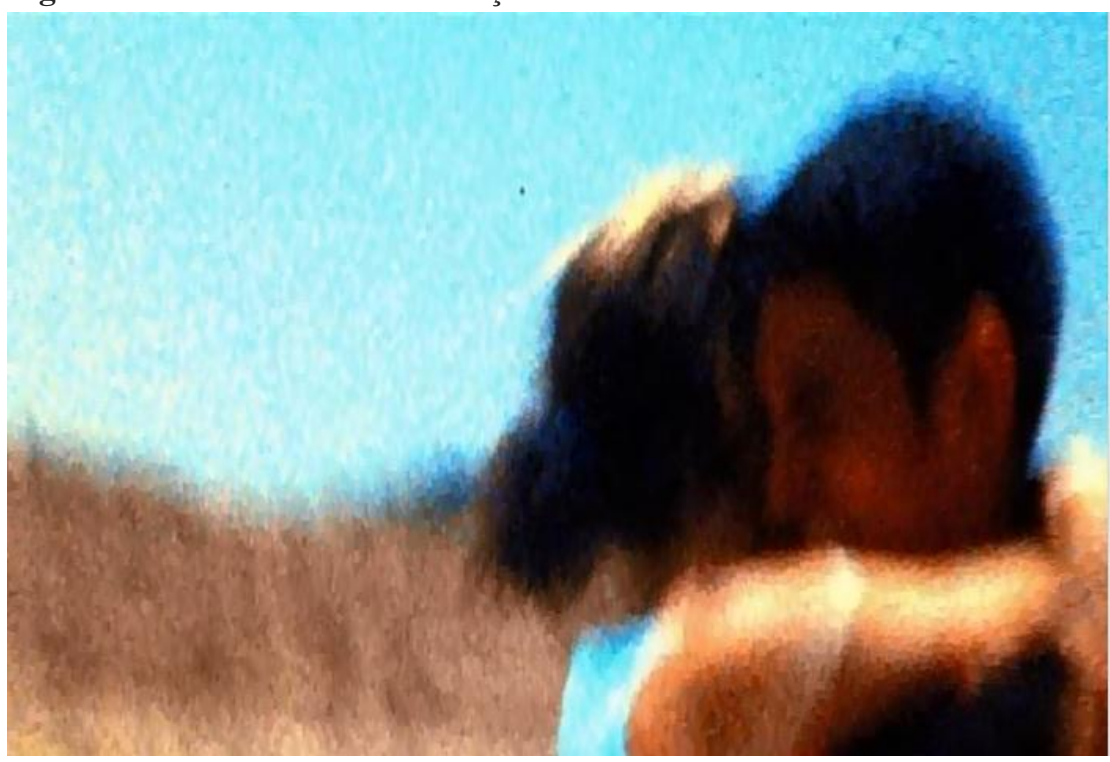

Fonte: O Céu de Suely (Karim Aïnouz, 2006) 
Antes de prosseguirmos com a nossa análise, é importante destacar dois aspectos. O primeiro é a importância do som na narrativa de $O$ Céu de Suely. Importância que é exposta logo nas cenas iniciais, precisamente no texto em que Hermila narra em voz off - "Matheus me pegou pelo braço e disse que ia me fazer a pessoa mais feliz do mundo, me deu um CD gravado com todas as músicas que eu mais gostava", pois há uma ênfase sonora quando a personagem pronuncia a palavra CD. Já o segundo, a relação entre a abertura da obra e a produção audiovisual contemporânea. Como destaca Vanoye; Goliot-Létté (1994), todo filme está inserido na história - seja em sua representação, como também na referência a outras obras - pois sempre traz um leque de influências em seu processo de composição. Dentro desse raciocínio, percebemos a sequência analisada (abertura) como um filme dentro do filme, e que se mostra, enquanto vídeo caseiro, em um diálogo com os filmes digitais. Uma metalinguagem, em referência ao cinema moderno, que coloca o cinema, como meio de expressão, pensando sobre si e sobre as formas de produção dentro do contexto contemporâneo.

Com relação a nossa investigação, o primeiro ponto a se abordar refere-se à produção de sentido por intermédio da trilha de imagem em paralelo com a trilha sonora. Se observarmos bem, percebemos que o discurso das imagens analisadas é oposto ao da trilha de som. Quanto a isso, Chion (2011) coloca que os aspectos auditivos (mesmo as canções) também apresentam caráter semântico, fato que observamos na cena analisada: o diretor utiliza a música em uma relação ambígua com a mensagem imagética. Nas fotografias abaixo (Figuras 2, 3), enxergamos que uma atmosfera de felicidade permeia o casal Hermila e Matheus, ambos sempre aparecem em meio a risos, abraços e beijos. Porém quando, da mesma forma, analisamos a letra da música imbricada com as imagens, aparecendo de forma extra-diegética, percebemos que a canção, interpretada por Diana, fala sobre nostalgia, espera e separação. 


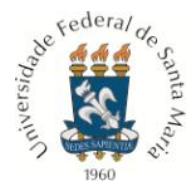

Figura 2: Hermila feliz e sorridente.

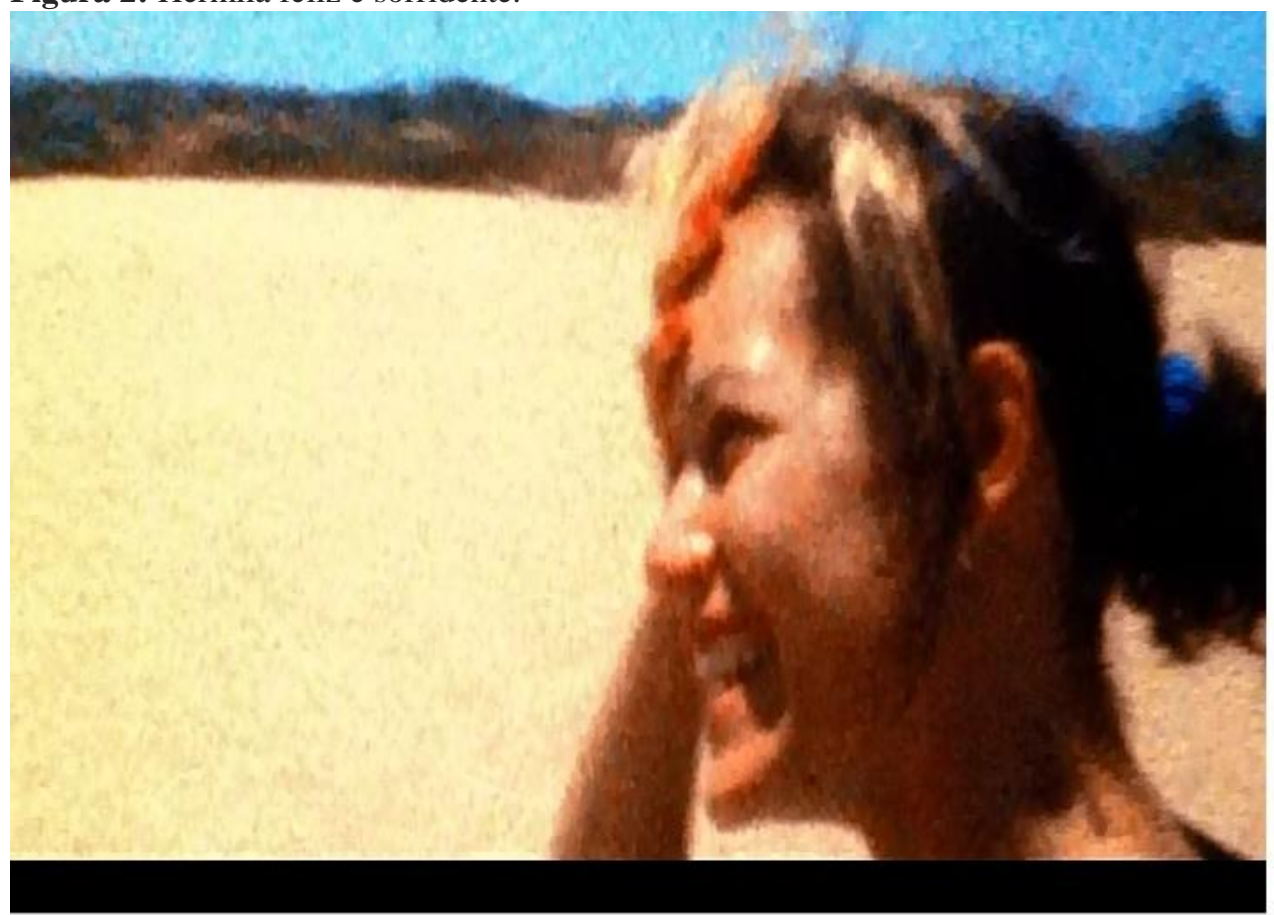

Fonte: $O$ Céu de Suely (Karim Aïnouz, 2006.

Figura 3: Hermila e Matheus se beijam.

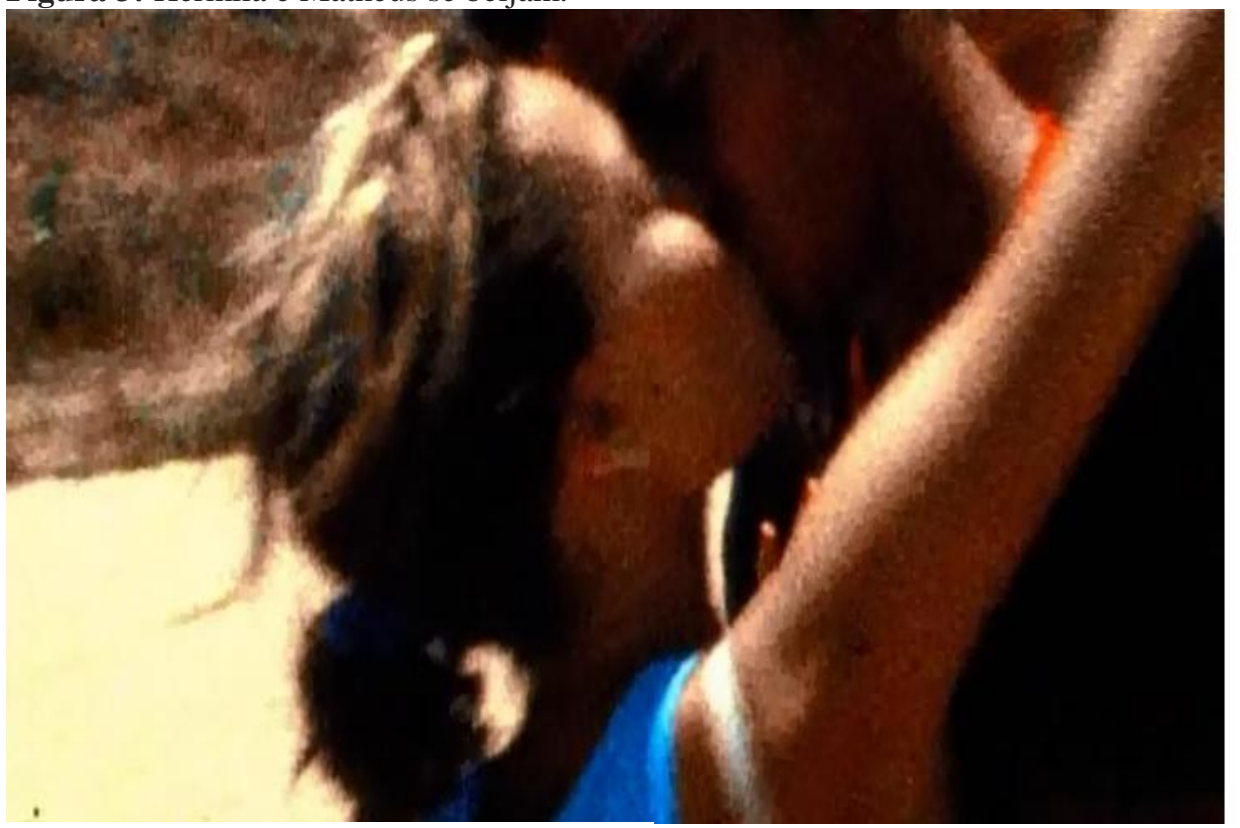

Fonte: O Céu de Suely (Karim Aïnouz, 2006).

O segundo aspecto observado está relacionado com trilha sonora e narrativa. Quando analisamos a construção "semântica da música" (CHION, 2011) em contraponto com as imagens, podemos perceber a canção como ferramenta de criação de significados. Nosso ponto de análise parte do princípio de que, na cena observada, a música - neste caso, diferente da imagem - antecipa o desenrolar da trama. Como já pontuamos, as imagens observadas 
colocam o casal, Hermila e Matheus, em momentos de felicidade, porém a canção trata sobre solidão, separação e nostalgia. Como conhecemos a narrativa proposta por Karim, percebemos que a trilha sonora estabelece um elo muito forte com o enredo: após a cena de abertura, a narrativa passa a tratar justamente do abandono de Matheus e da peleja de Hermila na tentativa de se reerguer diante dos fatos.

Vale salientar ainda, que observamos outros exemplos que colocam o filme de Karim Aïnouz dentro de uma perspectiva em que a trilha de som (músicas), no universo diegético, estabelece uma relação significativa com o desenrolar dos fatos. Como exemplo, podemos citar a sequência - que iremos denominar aqui - "encontro com João". No desenrolar da cena citada, podemos destacar a utilização da música, antes do encontro entre os personagens Hermila e João, como um mecanismo que transmite uma mensagem condizente com os acontecimentos posteriores da narrativa.

Na cena citada, uma atmosfera de dúvida permeia o pensamento de Hermila. Ela ainda não tem a certeza do abandono, mas já sente que algo de estranho está acontecendo, principalmente pelo fato de não conseguir mais falar por telefone com Matheus. A personagem decide sair com Maria. Elas vão para uma festa em um posto de gasolina. A música, intra-diegética, que toca no ambiente tem o seguinte refrão: "pode parar / com esse blábláblá / que por mim você / morre de amor / se você teve a chance / então pra que desperdiçou? / chega não dá mais / já te esqueci / eu quero encontrar alguém que possa me amar / entre eu e você tudo terminou..." enquanto a canção é executada, as cenas mostram imagens de Hermila dançando com riso no rosto e um ar de felicidade.

Na continuidade da sequência, a personagem Georgina Jéssica se aproxima e Maria apresenta a amiga para Hermila. Elas trocam algumas palavras e logo tem início outra canção da cena (também intra-diegética), no mesmo instante o olhar de Hermila encontra com João. Ela caminha em direção a ele e ambos iniciam uma conversa. O ponto chave, do trecho citado, é a canção executada durante o desenrolar da cena, cuja letra traz a seguinte mensagem: “coração / para que se apaixonou / por alguém que nunca te amou / alguém que nunca vai te amar / preciso sair dessa / dessa de me apaixonar / por quem só quer me fazer sofrer / por quem só quer me fazer chorar." É como se a personagem se questionasse, diante dos fatos, sobre a escolha que fez entre Matheus e João. E assim, nas cenas seguintes, Hermila tem a certeza do abandono, se envolve com João e, posteriormente, decide rifar uma noite de sexo. 


\section{CONCLUSÃO}

Buscamos com este artigo - por intermédio de um escopo teórico que coloca o cinema como representação visual e sonora - estabelecer uma observação mais detalhada na relação entre trilha de imagem e trilha de som, no filme de Karim Aïnouz. Neste trajeto, pudemos perceber que as discussões em torno de som e imagem, nos estudos sobre o cinema, estão relacionadas com a própria história do meio, porém vale destacar que, apesar de todo emaranhado teórico existente, compreendemos que tais discussões estão longe de um denominador comum, pois, na verdade, trata-se de um processo contínuo de novas descobertas e pesquisas.

É importante colocar que, como apontamos anteriormente, na narrativa fílmica reconhecemos marcas estilísticas, que na literatura são chamadas de dêiticos, nos indicadores que remetem diretamente ao diretor. Quanto a isso, em $O$ Céu de Suely, além dos aspectos imagéticos e sonoros que discutimos no decorrer deste texto, podemos citar ainda a adoção de uma estética realista, por meio do uso de som direto (ruídos de carros, motos, caminhões e alto-falantes, por exemplo), representando a sensação de opressão vivida pela personagem Hermila, como outro exemplo estilístico na composição do universo diegético.

Por fim, a partir de nossas análises, concluímos que as músicas que compõem a banda sonora exercem influência significativa no filme $O$ Céu de Suely. A partir das ideias de Chion (2011), analisamos som e imagem por meio de uma perspectiva de "valor agregado", haja vista que, no filme de Karim Aïnouz, a banda sonora aparece como um valor que se agrega à imagem para a criação de significado, sendo a força motriz que dita o andamento da narrativa. $\mathrm{Na}$ obra, o enredo estabelece uma relação muito forte com as canções, sendo elas, muitas vezes, um prenúncio dos fatos do universo diegético. Na cena analisada - no caso "abertura" - percebemos que som e imagem mantém uma relação antagônica, pois a trilha sonora remete aos fatos "reais" do enredo proposto, enquanto as imagens negam esses fatos. Sendo assim, fica evidente que é preciso "enxergar", muitas vezes, a trilha sonora com a mesma atenção que damos aos aspectos imagéticos, pois questões importantes da narrativa fílmica podem surgir a partir das canções executadas, assim como ocorre em O Céu de Suely. 


\section{REFERÊNCIAS}

AINOUZ, K. (diretor) (2006). O céu de Suely [DVD]. 90 min. Brasil / França / Alemanha: Vídeo Filmes.

AUMONT, J. O cinema e a encenação. 1. ed. Rio de Janeiro: Saraiva, 2011.

O filme como representação visual e sonora in: AUMONT, J. et al. A estética do

filme. São Paulo: Papirus, 1995.

BORDWELL, D. Figuras traçadas na luz. 1. ed. Campinas: Papirus, 2009.

CHION, M. A Audiovisão: som e imagem no cinema. Portugal: Texto e Grafia, 2011.

EISENSTEIN, S. A forma do filme. 2. ed. Rio de Janeiro: Jorge Zahar, 2002.

Continental. . (diretor) (1925). O Encouraçado Potemkin [DVD]. 75 min. Rússia:

GAUDREAULT, A.; JOST, F. A narrativa cinematográfica. 1.ed. Brasília: Editora Universitária de Brasília, 2009.

HITCHCOCK, A (diretor) (1960). Psicose [DVD]. 109 min. Estados Unidos: Paramount Pictures.

KELLY, G. (diretor) (1952). Cantando na Chuva [DVD]. 103 min. Estados Unidos: Warner Bros.

KUBRICK, S. (diretor) (1972). Laranja Mecânica [DVD]. 137 min. Estados Unidos / Reino Unidos: Warner Bros.

MARCOLINO, M. O compositor Stanley Kubrick: análise do som no filme De olhos bem fechados de Stanley Kubrick através da teoria sonora de Michel Chion. Belo Horizonte. $81 \mathrm{f}$. Dissertação (Mestrado em Cinema). Escola de Belas Artes, Universidade Federal de Minas Gerais, Belo Horizonte, 2012.

METZ, C. A significação no cinema. São Paulo: Perspectiva, 1977.

PENAFRIA, M. Análise de filmes: conceitos e metodologias. In: VI Congresso Sopcom, 2009, Portugal. Anais... Portugal: SOPCOM, 2009. p. 1-10.

ROSENFELD, A. Cinema: arte e Indústria. 1. ed. São Paulo. Editora Perspectiva, 2002.

VANOYE, F.; GOLIOT-LÉTÉ, A. Ensaio sobre a análise fílmica. 1. ed. Campinas - SP: Papirus, 1994.

VERNET, M. Cinema e narração. In: Aumont, J. et al. A estética do filme. São Paulo: Papirus, 1995. 
Doutorando no Programa de Pós-Graduação em Ciências Sociais da Universidade Federal do Rio Grande Norte (PPGCS / UFRN)

Bertrand Lira

Professor Doutor do Programa de Pós-Graduação em Comunicação da Universidade Federal da Paraíba (PPGC / UFPB) 